\title{
National machinery for gender equality in Sweden and other Nordic countries
}

\author{
BIRGITTA ÅSESKOG
}

\section{Introduction}

In this chapter I want to describe the 'Nordic model' of national machinery for gender equality. I want to show the similarities between the countries, but also the differences. The official Nordic cooperation on gender equality, conducted by the Nordic Council of Ministers, is based on the development of pilot projects and reports on priority areas. It provides excellent opportunities to develop new methods and strategies and is a forum for the exchange of experience. This cooperation is of great importance for progress in all countries in the equality policy area.

I argue that the development of a Nordic mainstreaming strategy is an important next step in the efforts to promote gender equality in this region. I conclude this chapter with a focus on the specific case of Sweden. ${ }^{1}$ Norway was the first Nordic country to start systematic work to mainstream a gender perspective in all policy fields (early in the 1980s). The other countries have recently started to develop their mainstreaming strategies. In 1996 the Nordic Council of Ministers decided to launch a three-year project (1997-99) in order to develop methods and tools for the integration of a gender perspective into labour market policy and youth policy in the Nordic countries. 


\section{Nordic cooperation and a 'Nordic model' of gender equality}

The Nordic countries have strong cultural, historical and linguistic ties, as well as firmly rooted democratic traditions. This has enabled them to succeed in developing a pattern of close, constructive cooperation in various areas. Official Nordic cooperation involves the five Nordic countries of Denmark, Finland, Iceland, Norway and Sweden, as well as the autonomous territories of the Faeroe Islands, Greenland and Åland, with a total of 23 million inhabitants. The Parliaments cooperate in the Nordic Council and the governments cooperate in the Nordic Council of Ministers. The cooperation is not supranational but based on voluntary equal cooperation between independent nations. Several Nordic institutions and project activities are funded from a Nordic budget. As a result of the significant levels of cultural homogeneity of the countries and cooperation between their governments, the Nordic countries have achieved more or less uniform legislation in some areas. One of these areas is gender equality, where the countries have agreed on certain standards and adopted common goals.

Cooperation programme for gender equality, 1995-2000

Cooperation on gender equality among the Nordic countries is based on projects and reports commissioned by the Nordic Council of Ministers. In the build-up to the Beijing Conference on Women, the Council launched an initiative called 'Cooperation programme in the equality area 19952000'. The main goal of the initiative was to promote the further development of a united Nordic approach to the issue and a common Nordic platform within the framework of broader European and international cooperation. It emphasized that gender equality aspects must be implemented in all areas of society and in the areas covered by the Nordic Council of Ministers' own programmes and projects (the implementation of a mainstreaming strategy). The activities have focused on:

- promotion of equal access for women and men to the political and economic decision-making processes; 
- promotion of equal economic status and influence for women and men. Particular emphasis will be placed on steps to promote equal pay;

- promotion of gender equality in the labour market;

- improved opportunities for both women and men to combine parenthood with a job;

- measures to influence European and international developments in the field of gender equality;

- development of methods of promoting active steps to achieve gender equality.

\section{Common policy framework}

Equality between women and men is a crucial part of the Nordic welfare state model. In an international perspective the Nordic countries enjoy a very high standard of living. Moreover, they have made considerable progress in their efforts to promote equality between women and men since the 1980s. The political view prevails that society can progress in a more democratic direction only when the competence, knowledge, experience and values of both women and men are acknowledged and allowed to influence and enrich developments in all spheres of society. Although there are some differences between the systems of the different countries, the similarities are such as to create a 'Nordic model' of gender equality. The Nordic model is based on the assumption that women and men have the same rights, obligations and opportunities in all essential areas of life. This broad concept of equality in turn imposes demands on the fundamental structure of society and its various functions.

Economic independence is the foundation of the Nordic gender equality policy. An important aspect is, therefore, to enable both women and men to reconcile economic activities with parenthood. This is reflected in the labour force participation rate, which, for both women and men, is one of the highest in the world. From the age of twenty until retirement, between 72 and 83 per cent of women and 81 and 92 per cent of men work in the labour market in the five countries (Nordic Council of Ministers, 1994). But even though women represent a large part of the labour market, there are considerable differences between men's and women's positions there. Women work part time to a larger 
extent than men; women are mainly employed in the public sector in care- and service-related jobs, men in private enterprises; and women have non-managerial jobs, whereas men form the majority of managers and bosses. There are also differences in earnings between women and men (between 11 and 12 per cent in industry) although the differences have decreased since the 1980s. The sex-segregated labour market is one of the explanations for the wage gap between women and men. Sex segregation is more of a problem than direct wage discrimination since the wages are low in those workplaces and positions in which women work - and higher where men work (Nyberg, 1997). Altogether, the differences between women and men in terms of working hours, occupation and job levels result in lower incomes for women compared with men.

In parallel with women's rising participation rate in working and public life, the Nordic countries have developed public child-care facilities and other forms of family support such as parental leave programmes and support for single parents (mostly mothers). The support combines general economic cash support with various kinds of service and assistance for the families. There are parental leave programmes, including wage compensation after the birth of the child, in all the countries. It is well recognized that the distribution of the workload between women and men in the family, in working life and in society must be changed, and that the active involvement of men is necessary if gender equality is to become reality. Therefore, a variety of initiatives have been launched to improve the everyday life of families with children and to give fathers in particular the opportunity to take active responsibility for their children. For example, in Norway and Sweden provisions on leave for men only have been introduced, which stipulate that four weeks of the joint parental leave can be taken by the father only.

Issues concerning men and equality have accounted for much of the policy work on equality between women and men in the Nordic countries since the 1980s. All the countries have had, for shorter or longer periods, so-called 'ideas groups' on issues concerning the male role, functioning as advisory committees to the Ministers for Equality Affairs. In 1995, a Nordic conference on 'Nordic men' was held in 
Stockholm at the initiative of the Nordic Ministers for Equality Affairs. A conference report was compiled by the Nordic Council of Ministers, and was available at the United Nations (UN) Fourth World Conference on Women in Beijing. The report paints a broad picture of current changes in men's view of masculinity, new family patterns, the role of the father, the caring professions, and men and violence. The positive experiences arising from the Conference have led, among other things, to the adoption of a three-year action plan on men and equality (1997-2000). The plan covers such things as themes for seminars, cooperative projects, network building and research projects.

\section{Equality legislation and national machineries}

Shared power between women and men is another cornerstone of the gender equality policy. Nordic women have had the same political rights as men since the beginning of the twentieth century. They gained the right to vote between 1906 and 1919 and the right to be elected between 1907 and 1922. However, women do not yet participate in political life on equal terms with men, although their representation on political bodies is higher than in any other part of the world. In Norway and Sweden about 40 per cent of Members of Parliament are women, in Denmark and Finland about 35 per cent and in Iceland 25 per cent. Sweden has the highest proportion of women at ministerial level - eleven of the twenty ministers are women. Norway has had a woman Prime Minister - Gro Harlem Brundtland - for many years and Vigdis Finnbogadóttir was President of Iceland from 1980 to 1996.

The preparation of decision making is an essential part of exercising influence. Laws that have important policy implications are generally prepared by state commissions, committees, advisory boards or similar preparatory bodies. The Nordic countries have applied partly divergent strategies to increase women's representation on these decisionmaking bodies. The countries have different opinions on the merits of quota systems as an instrument for achieving greater gender equality regarding the composition of 
decision-making bodies. In Denmark, Norway and Finland legislation has proved effective in increasing the percentage of women appointed to public bodies, while in Sweden strong political will, clear goal setting and strategic administrative procedures have given good results. Other strategies which are playing an increasingly important role in all countries are new forms of cooperation between women; for example, cooperation across party boundaries and the setting up of loosely structured (informal) women's networks.

Although non-governmental organizations (NGOs) are not considered part of the national machinery for gender equality, women's organizations are nevertheless a vital factor in influencing attitudes and awareness of gender issues. They also have an important role as pressure groups for the development of equality policy in the Nordic countries. Cooperation between the governments and the NGOs is very close. Governments give financial support to women's organizations and representatives of NGOs are included in official national delegations to international forums.

Despite similar principles and goals, the Nordic countries have chosen somewhat different ways of establishing gender equality by law. The systems of law enforcement and organizational structures also differ to some extent. In Norway, Sweden and Finland, a Gender Equality Ombuds person ensures that the relevant Act on gender equality is duly complied with, while other bodies (e.g., councils) draft policy on this issue and related matters. In Iceland, a Gender Equality Council is responsible for both drafting the policy and the implementation of the relevant legislation. The details of the structures vary: despite apparent identity, no two systems are completely alike. All the Nordic countries, however, share the defining feature that work on gender equality is overseen by public offices connected to, and set up by, the central authorities. The gender equality legislation is also in accordance with that of the European Union and with other international conventions such as the UN Convention on the Elimination of All Forms of Discrimination against Women.

While the emphasis of legal provision for gender equality is similar, the details vary. In Denmark, for example, the national machinery is under reconstruction. In 1999, the Prime Minister appointed a Minister for Gender Equality, 
who has overall responsibility for the government's policy on gender equality. As one of her first tasks the Minister introduced a new organization of the work with gender equality in Denmark. The gender mainstreaming strategy is consolidated as official Danish policy. All ministers have within their remit a responsibility to promote gender equality. The underlying state institutions and organizations will every second year report to the relevant minister on efforts to promote gender equality and all ministers of the government will then report to the Minister for Gender Equality. Each year the minister is under an obligation to deliver a review on the previous year's progress and action plan for the coming year's work to Parliament. Each minister is responsible for pursuing a balanced representation of women and men in public boards and committees, and the ministers have the right to leave seats empty should nominating parties, without an adequate explanation, fail to suggest both women and men for the seats in question.

If the legal provision is varied within the Nordic region, so are the national machineries overseeing the process of initiating policy and implementation of the laws. Denmark, for example, has three laws on equal opportunities:

- The Equal Treatment Act (1976). Equality in the labour market and with regard to vocational and professional training (women and men may not be discriminated against on the grounds of gender).

- The Equal Pay Act (1985). Men and women are entitled to equal pay for the same work or for work of equal value.

- The Act on Equality between Women and Men (2000). Establishes the principle of gender equality, the possibility of using preferential treatment, the national machinery, and rules concerning the participation of women and men in public committees and boards.

In Finland the 1987 Act on Equality between Women and Men has three goals: the prevention of sex discrimination; the promotion of equality between women and men; and the improvement of women's status, especially in working life. Temporary positive action based on equality action plans is permitted. Since 1995 the Act has included a quota provision: in official committees and councils the proportion of representatives of either sex should not be below 40 per cent. 
In Iceland the first Act on the Equal Status and Equal Rights of Women and Men came into force in 1976 (revised in 1991). It aimed at establishing equal rights and equal status of women and men in every sphere and prohibiting any form of gender discrimination. In May 2000, a new Act on the Equal Status and Equal Rights of Women and Men was passed. A new Centre for Gender Equality has been established which is in charge of administering the new Act, as well as providing counselling and education in the field of gender equality for governmental and municipal authorities, institutions, companies, individuals and NGOs.

In Norway the Equal Opportunity Act took effect in 1979 and applies to all parts of society. The Act promotes equality between the sexes and aims particularly at improving the status of women. Public authorities have to change conditions in order to achieve equality within all spheres of society. Women and men need to have the same opportunities for education, employment and equal pay for work of equal value. The Act prohibits any form of discrimination, but stipulates that positive action for improving equal status is not contrary to the law. The Act has been supplemented by collective agreements in most parts of the labour market.

In Sweden, the Equal Opportunity Act has been in effect since 1992. It supersedes the 1980 legislation on equal opportunities. The Act is restricted to working life and its main purpose is to promote equal rights for women and men with respect to employment, working conditions and opportunities for personal development at work. The Act aims to improve conditions for women in working life. It has two main parts: rules prohibiting an employer from discriminating against a person because of gender; and rules requiring an employer to take active steps to promote equality in the workplace. Employers are to make it easier for both women and men to combine parenthood and work. Similarly, employers are to counteract differences in pay and other conditions between women and men who perform equal work or work of equal value. Steps must also be taken to ensure that no employee is subjected to sexual harassment. Employers with ten or more employees must present an annual plan for the promotion of equality at the place of work, including a survey of pay differentials 
between their female and male employees and a report on measures taken.

\section{Gender mainstreaming: a step towards gender equality}

Gender equality work in the Nordic countries is currently going through a very important and exciting phase. Mainstreaming strategies are developed and used as a complement to more traditional equality strategies. The adoption of the Platform for Action by the Fourth World Conference on Women in Beijing in 1995 has been of great importance for that development. Governments have agreed to 'promote an active and visible policy of mainstreaming a gender perspective into all policies and programmes, so that, before decisions are taken, an analysis is made of the effect on women and men respectively' (PfA: 79, 123, 164) in important policy fields. The challenge for the governments of the Nordic countries is now to implement this agreement.

In the 1970s and 1980s equality policies were introduced at national level. Institutional mechanisms such as Equal Status Councils, Gender Equality Acts and Equality Ombuds persons were established. As Drude Dahlerup (1988: 8) has commented on this phase of the equality work:

These new agencies constitute the first institutionalization of the equality policy, which was previously conducted solely as pressure group politics by voluntary associations. Although their resources and influence are limited, these new agencies exemplify the mobilization of institutional resources for improving women's position. Also in the regional labour market authorities, in the public administration and in large firms and trade unions, staff are now being hired with equality policies as their area of responsibility.

In the 1950s, feminists would not have dreamt of a situation in which people would actually get paid for work on equality between women and men.

Now, these institutional mechanisms are well established and recognized as an important part of the democratic system. This recognition is crucial for the next stage in attaining gender parity. While the emphasis on equality legislation in the 1970s and 1980s was an important step 
towards addressing gender issues in public life, it has also become clear that by themselves these measures were not enough to tackle the issue.

Along with measures taken to ensure formal equality through legislation, implementing measures are needed. It has become more and more obvious that awareness-raising campaigns, pilot projects and different ways of making up for deficiencies by introducing supplementary measures (e.g., the improvement of women's skills and competence) are not enough. New strategies and methods must be developed, aimed at changing the societal structures which still maintain sex segregation (e.g., the unequal power relationship between the sexes, the sex-segregated labour market and the gender-based distribution of family responsibilities). Much of the equality-promoting work has so far been organized as projects outside ordinary policy processes, often financed by special funds for a limited time. It has been sidelined and not really affected societal structures. A Swedish researcher, Gertrud Åström, has described this sidelining as an 'impressive equality annex, where activities can take place, leaving the rest of the political house largely undisturbed' (Åstrom, 1994:2).

A shift of strategies from targeted equality policy to gender mainstreaming is a step towards the goal — de facto gender equality. Gender mainstreaming addresses the problem of sidelining directly. It aims at taking gender equality issues into the mainstream of society, into ordinary policymaking processes in all areas. It involves the reorganization of policy processes because it moves the attention of gender equality policies to everyday policy processes and to the activities of the actors ordinarily involved in policy shaping. Making gender issues visible and integrated into the mainstream of society will lead to changes in genderbiased societal structures. But prerequisites for successful gender mainstreaming are a strong political will at the highest level and a national machinery with the mandate, tools and resources to exert influence on the policy process at all levels. However, it is important to underline that a national machinery has a catalytic role in facilitating and supporting the mainstreaming process. It should work to ensure that the highest levels of government and administration take responsibility for equality-promoting work 
within their fields of responsibility. The case of the national machinery of Sweden illustrates the strengths as well as areas of concern that face national machineries in the Nordic region.

\section{Gender mainstreaming in Sweden: national, regional and local levels}

A national machinery for the advancement of women has been in place at central governmental level since the early 1970s. Also since the 1970s, a Cabinet minister has held overall responsibility for the government's policy for gender equality. However, since there is a conviction in Sweden that a policy for equality cannot be developed independently of other policy areas, each minister in the Swedish government is responsible for promoting, analysing, evaluating and following up the work for equality in his or her field of responsibility. From 1994 onwards the Prime Minister has declared in the annual statement of government policy that the gender equality perspective should be taken into account in the preparatory proceedings of all decisions by the Cabinet. This written statement is an important legitimate base for the implementation of mainstreaming methods. It is often referred to in the dialogue on gender issues between the Division for Gender Equality, located in the Ministry of Industry, Employment and Communications, and the other ministries.

Another important tool for mainstreaming is the requirement that all government committees of inquiry have to analyse and discuss their proposals from a gender perspective. The gender impact - whether direct or indirect - of proposed changes in the labour market, in the economy, in the welfare system, in education should be described. If the committee or the special commissioner considers it impossible or unnecessary to do this, the reason must be stated. Training courses are offered to all special commissioners and their secretaries in order to help them fulfil the requirements.

The Division for Gender Equality has overall responsibility for developing tools and mechanisms for mainstreaming 
and for supporting and pushing through the work for equality at national and regional levels. The Division also reviews proposals for government Bills and other government decisions emanating from various ministries. This is to ensure that a gender perspective has been taken into account and to monitor the work towards fulfilling the target of an even distribution of women and men in committees and state boards. It is important to note, however, that the Division's role is to promote, encourage and support initiatives/activities to promote gender equality. The actual work of ensuring that the gender impact is considered in the administrative proceedings, for example in planning processes and budgeting, rests with the staff of each ministry/division.

At regional level the County Administrative Boards, which are government authorities, are responsible for mainstreaming the gender perspective in all policy fields. The Boards have employed gender experts to start, support and monitor the process of mainstreaming a gender perspective in ordinary policy processes in all relevant areas. A medium-term strategic plan (1997-2000) for the equalitypromoting work has been designed by each Board and submitted to the government.

In order to stimulate the development of a mainstreaming approach to gender equality work in the municipalities, the government allocated funds in 1995 to the Swedish Association of Local Authorities. A two-year programme was launched with the aim of examining how a committee or board can work systematically for gender equality in its own field of operation. The $3 \mathrm{R}$ method, the main purpose of which is to systematize a gender equality analysis, was tried out in the programme (see Appendix at end of chpater).

The cornerstones of the mainstreaming strategy therefore are:

- Responsibility at the highest level. Strategies and tools are needed to make it clear that overall responsibility for the implementation of gender mainstreaming rests with the highest level of government and public administration.

- Making gender visible. To this end, statistics disaggregated by sex are indispensable. The government has therefore given instructions to Statistics Sweden to 
present all official statistics, to be disaggregated by sex. The same goes for public authorities which produce statistics in their fields or which are request statistics from Statistics Sweden.

- Increasing the knowledge on issues related to gender equality. A mainstreaming strategy implies that not only gender experts but also other staff will deal with equality issues as part of their daily work. In order to do this they need knowledge. What is most important is that the toplevel management has sufficient knowledge to fulfil its duty to mainstream a gender perspective in its field of responsibility. Awareness raising and training seminars on gender equality for top-level management were first arranged by the Equality Affairs Division in 1994. Most of the ministers, state secretaries, political advisers, special commissioners and press secretaries in the Cabinet Offices have already attended. The training is now being extended to all top managers of the public sector. The main aim of the training is to provide basic facts on the situation of women and men respectively in Swedish society and to discuss equality issues in relation to the national goal for equality.

- Developing methods and tools. Although each ministry is responsible for the development of methods and tools for the integration of a gender perspective in their field of responsibility, the Equality Affairs Division has an overall responsibility to encourage and support the development. To this end a 'flying expert' on gender issues has been engaged to help some of the ministries develop tools and routines which ensure the integration of a gender perspective in policy processes (such as gender statistics, training courses, checklists and follow-up procedures). An analytical tool to check gender relevance and assess the different effects on women and men of policy proposals has been developed and distributed to the ministries.

In order to stimulate the development of tools for gender mainstreaming, a Working Group Chaired by the State Secretary for Equality Affairs and with representatives from central, regional and local levels was set up in January 1998. The focus of the Working Group is on developing methods and models that facilitate the 
implementation of the gender perspective in policy and administrative processes, which means turning knowledge into practice. The purpose of many of the methods developed hitherto has been to facilitate gender impact analysis in a certain area of policy making.

Another Working Group has been assigned to develop ways of incorporating a gender equality perspective into all parts of the budget process. This group includes representatives of the Ministries of Finance, Education and Industry, Employment and Communications and of experts from the National Institute for Working Life, Statistics Sweden and Linköping University.

- Monitoring and follow-up. The State Secretary for Equality Affairs meets regularly with her colleagues from other ministries to discuss, inter alia, gender impact analyses and promotion and evaluation of measures undertaken. In order to supply Parliament with information on the development of the mainstreaming process in the government, all ministries had to review and report on their equality work (from 1994 to 1996) to the Minister for Equality Affairs.

In 1997 an assessment was carried out on the effects of the special terms of reference (1994), which stated that all government committees of inquiry should analyse and discuss their proposals from a gender perspective. The assessment showed that 33 per cent of a total of 193 committees of inquiry had discussed their results from a gender perspective, although very few of them had presented a comprehensive gender analysis.

The Swedish National Audit Office has been directed to scrutinize how the gender equality aspect is reflected in the government's administrative control of the various national agencies and in their reports back to the government.

The mainstreaming process has only just begun in Sweden and it is not possible to evaluate effects on policy processes in general. My experience, however, is that the mainstreaming strategy has raised awareness in society of the relevance of gender in all policy making. There is also a growing awareness of the need to analyse both proposals and the distribution of resources from a gender perspective. A growing number of men are actively involved in gender equality 
policy making since gender issues are integrated into the ordinary work of the ministries. A growing number of mainstreaming tools and methods have also been developed by ministries; for example, a manual on gender equality in development cooperation (Ministry for Foreign Affairs), an action programme for the development of mainstreaming procedures (Ministry of Health and Social Affairs), a commission on gender mainstreaming (Ministry of Industry, Employment and Communications) and a Bill to Parliament on gender equality at the universities (Ministry of Education and Science).

However, many politicians and officials at the ministries still lack knowledge on gender issues. It can be hard to understand what it means (in a concrete way) to take a gender perspective into account in their normal work. A common misunderstanding is that equality-promoting work deals only with personnel policy, for example by setting up targets for the recruitment of women, training of women leaders, and so on.

The arrangement of seminars on gender issues and the further development of educational tools are therefore important. Equally important is the development of analytical and monitoring tools. Implementing a mainstreaming strategy is a long-term procedure.

\section{Conclusions}

I have described a 'Nordic model' of gender equality policy and national machinery which to a certain extent has been successful. De jure equality between women and men has been achieved in all countries. Although much remains to be done, a continued positive development towards de facto equality is under way. It is important to realize that this 'model' is based on a long democratic tradition in all the Nordic countries and that people in general have confidence in the political system.

Institutional mechanisms for gender equality, equality legislation and the implementation of measures to promote equality neither can nor should be structured in the same way in all countries. Differences in political and bureaucratic 
systems, cultural differences and so on must be taken into account in order to choose efficient structures. However, information on different ways of organizing national machineries and exchange of experience is one way of stimulating the further development of work to promote gender equality in all countries.

\section{Appendix: 3R for mainstreaming at local level ${ }^{2}$ GERTRUD ÅSTRÖM}

The JÄMKOM ('Gender Equality in the Municipalities') project has, within the framework of the Programme Group of the Swedish Association of Local Authorities (SALA), developed and tested a method, the 3R method, for incorporating gender equality considerations into the work of local authorities. The strategy on which the project is based is 'mainstreaming'; that is, the idea that gender equality is not regarded as a separate issue, but is observed and given concrete expression in the everyday activities of the authority.

\section{The project}

During the spring of 1996, work began with the formulation of the ideas behind the $3 \mathrm{R}$ method. An invitation then went out to all local government committees and boards in Sweden to take part in testing the method. In early autumn of the same year a selection of the committees and boards was made on the basis of certain criteria: geographical distribution; variation in size and political composition of the municipal councils; committees and boards from different fields; previous experience of working with change and development within their field of operations; and, ideally, previous experience of work with gender equality. Of these criteria, variation in political composition of the councils was not achieved.

The following municipalities and committees/boards were selected: Haparanda, Social Services Committee and Child and Youth Welfare Services Committee; Skellefteå, Leisure and Recreation Committee; Södertälje, Town Planning Committee; Köping, Social Services Committee and Education 
Committee; Växjö, Cultural Amenities and Recreation Committee, and Municipal Executive Board; Göteborg, Recreation Committee.

In September and October 1996, the ideas behind the project were presented at an introductory meeting with the relevant senior officials from the local authorities; that is, the municipal commissioners, the chairpersons of the committees and boards, and administrative heads. The conditions for participating in the project were set out in a contract detailing reciprocal commitments, such as the requirement that the committees/boards apply JÄMKOM methods at a minimum of five meetings during the project period, and that they would receive SEK 40,000 to cover the extra costs incurred. A timetable was presented. It was made clear that the tests should be conducted using the usual staff, and that the committees/boards were at liberty to limit the JÄMKOM work to certain areas of their activities.

At the first JÄMKOM meetings held by the committees/ boards, the background to the project was presented. SALA's work for gender equality and the $3 \mathrm{R}$ method were presented and a talk was given on Sweden's gender equality policy and gender theory. All members of the committees/ boards and the officials involved were given two JÄMKOM compendia to help them with the project. The first compendium contained factual and background information, whereas the second was a work file in which the different phases of the project were set out, from inventory, through statement of objectives, to final assessment of the project.

Each committee/board appointed a local project leader. It was they who drew up a local project plan and tested the $3 \mathrm{R}$ method in their respective towns, together with other colleagues and politicians and in close collaboration with project officials at SALA. The results of the $3 \mathrm{R}$ tests have always been discussed at a meeting of the committee/board.

The local authorities project ended in mid summer 1997, and the various committees/boards presented reports of their work in autumn of that year. Specific training courses were developed by SALA on the basis of the project. Several municipalities have trained their officials in order to start implementing the $3 \mathrm{R}$ method. 
The $3 \mathrm{R}$ method is based on a systematization of Swedish experience of work on gender equality, and has also been inspired by other methods used in gender and action research. 3R stands for Representation, Resources and Realia. Representation and Resources are quantitative variables, whereas Realia is qualitative. The idea behind the method is that a systematic review of men's and women's representation in different places and positions within the committee's/board's field of operations, and of the distribution and utilization of resources, would trigger discussions about why the products the municipality produces - goods, services and situations - are as they are, who gets what and under what conditions. How do the activities of the local authorities work for the people who live there?

The tests that have been carried out by the councils/ boards have shown that the method really does work in that way. The surveys and analyses that have been carried out have led to the rethinking of gender equality in the committees'/boards' spheres of operations, including the writing of specific gender equality objectives into their guidelines. Some have also decided to include gender equality in their budgets, to collect new and continuous information in the form of statistics and different types of customer surveys, and to monitor actively the impact of the different measures. The 3R method has been adopted, and some municipalities have decided to spread the method to other committees and administrative authorities.

\section{Representation}

The first part of the methodology deals with looking at how women and men are represented in the committee's/ board's field of operations. The simplest way is to begin with the composition of the committee/board itself and then to go on to the administration. The existing organization is studied and the positions in the hierarchy occupied by women and men are mapped out. From this initial plan, the study of representation can move on to other committees, working groups, permanent reference groups, ad hoc reference groups, and the committees of associations and organizations within the field of operations and with which 
the board/committee and administration have dealings. How are women and men represented among those who contact a committee/board to raise an issue?

The different committees/boards have carried out different studies, but common to all has been that politicians and local government officials have kept 'contact lists'. For at least two weeks they systematically noted down all the contacts they had in their work. They recorded whether the person concerned was male or female and acting as a private citizen or as a representative of an interest organization. This was done in order to raise awareness of the distribution of representation among those with whom the politicians and officials come into contact and from whom they receive information. The contact lists led to lively discussions, including why some politicians reported that they had had no contacts at all, and the differences between the number of contacts recorded by paid and unpaid politicians. 'How representative are the representatives?' was one question that was raised.

\section{Resources}

The resources analysed by the $3 \mathrm{R}$ test are money, time and space. The main idea was that the results obtained under the Representation section could be supplemented by statistics concerning the distribution of resources. One example of this is that certain committees/boards have constructed 'salary trees' showing the total number of women and men and their position on the salary scale. One committee studied the gender distribution among artists exhibiting at the local art gallery, and the information was completed under the resources section of the test by recording how much money was paid to the female and male artists respectively. The amount of funding distributed to different cases, subject areas and organizations has also been studied.

All the committees/boards have timed some of their meetings. Some decided that it should be done without the members knowing exactly when, while one chose to use a chess clock on one occasion. Besides recording how much women and men talked at the meetings, more detailed analyses of the measurements were carried out. Often the distinction made was between politicians and 
officials, and chairperson and other members. One finding that gave rise to interesting discussions was that officials often talked more than politicians at committee/board meetings.

One study of how the 'space' resource could be measured was carried out at a day nursery, with the staff themselves observing how girls and boys made use of a particular demarcated area.

Realia

Realia is qualitative, and is about the norms and values expressed in the structure that produces the local authority activity - that is, committees and boards, administrative authorities and work places - and the products that are produced - that is, goods, services and situations. Who recognize themselves in it? Whose needs are served?

Some committees/boards have looked at the Realia by studying, together with staff, such things as morning assembly at day nurseries and classroom situations. Others have visited different establishments for which they are responsible. The politicians have formed multi-party groups and gone to places such as sports centres and made note of such things as lighting, hair-dryers and sauna space. They have also interviewed employees about the amount of attention they give to girls and boys, women and men. One committee working with meetings between the administration, politicians and employees has decided that gender equality is to be a regular annual theme for a meeting when the results of the previous year's decisions and measures are to be followed up. The politicians who have been involved in different studies have expressed themselves as satisfied. Some have said that they have received greater insight into their field of operations and that they better understand what gender equality really means and how they can specifically work for it.

The town planning committee that took part in J̈̈MKOM has used 'mental maps' to help build up an understanding of how different categories of citizens feel about a particular urban renewal area. This involved groups not to be found among the normal reference groups in the committee's field of operations. 


\section{Notes}

1 I have worked for the government of Sweden at the Equality Affairs Division as a principal administrative officer since 1990.

2 This Appendix is based on the 1998 report, Gender Mainstreaming: Conceptual Framework, Methodology and Presentation of Good Practices, Final Report of Activities of the Group of Specialists on Mainstreaming (E-S-MG). Copenhagen, Council of Europe. 